\title{
Dossier 'Gezondheidszorg\&arbeid' nog niet op orde
}

\author{
Peter Buijs
}

Na enkele huisartsenjaren betrad ik in 1980 de fascinerende wereld van WAO en ziekteverzuim. Een sociaalgeneeskundige onderzoeksbaan op het snijvlak van gezondheidszorg, sociale zekerheid en arbeidsomstandigheden - beleidsterreinen in voortdurende verandering, vol institutionele belangen. Gescheiden werelden vaak: iemand is in de ene wereld patiënt, in de andere verzekerde/verzuimer/'misbruiker', in de derde werknemer. Niemandsland ook rond de scheiding behandelingcontrole, waar medici en anderen allerlei goedbedoelde activiteiten ontwikkelden, maar afstemming vaak ontbrak en werknemers verweesd ronddoolden. Gezondheidszorg\&arbeid: toen bepaald geen dossierop-orde...

Over de artsenbemoeienis vroeg de overheid in 1983 advies aan de Raad voor Volksgezondheid. Dat kwam in 1987, waarna in 1992 het kabinetsstandpunt Sociaalmedische begeleiding verscheen, negen jaar na aanvraag: geen signaal van urgentie! Maar de uitgangspunten kondigden wel ingrijpende beleidswijzigingen aan: verantwoordelijkheidsverschuiving voor verzuim van bedrijfsvereniging naar bedrijf, verplichte ondersteuning door deskundige (arbo)diensten en betere arbocuratieve samenwerking. Aan de eerste punten is veel gedaan, vooral wettelijk, aan het laatste weinig. Vanaf 1994/ 1998: ver-plichte arbodienst; TZ/Arbo (1994): zes weken loondoorbetaling voor grote bedrijven, twee weken voor kleine; Wulbz (1996): 52 weken doorbetaling voor álle bedrijven, later zelfs 104 weken. En vanaf 1995 werden eindelijk ook enkele bescheiden arbocuratieve onderzoeken, experimenten, opleidingsmodules en

Peter Buijs $(\bowtie)$

Peter Buijs, bedrijfs-arts, is senior advi-seur/onderzoeker TNO Kwaliteit van Leven/Arbeid. Op 18-11-2005 werd zijn 25-jarig dienstverband gevierd met een invitational conference in het SER-gebouw. In deze column blikt hij terug op die 25 jaar. instrumenten gerealiseerd. De budgetten waren echter volstrekt onvoldoende om substantiële veranderingen te bewerkstelligen.

Als we na 25 jaar een voorlopige tussenbalans opmaken van dit complexe dossier, dan is enerzijds het nodige bereikt: beter inzicht in de problematiek - de 'blinde vlek' voor werk in de gezondheidszorg; gebrekkige arbocuratieve afstemming; organisatorische knelpunten als wachttijden; de nog steeds onheldere bedrijfsartspositie, e.d. -, in oplossingsrichtingen, randvoorwaarden en belemmerende/bevorderende factoren daarvoor; bestuurlijk draagvlak voor verandering; leerzame experimenten op beperkte schaal; en een groeiend besef, ook onder 'veldwerkers', dat het beter moet. En het project Ziek\&Mondig heeft eindelijk ook de patiënt/werknemerpositie ingevuld.

Anderzijds blijkt uit diverse studies, dat vooruitgang in de alledaagse medische praktijk vooralsnog ruim onvoldoende is. Daarvoor is geen eenvoudige verklaring. Hebben alle betrokkenen wel voldoende 'welbegrepen eigenbelang' bij betere arbocuratieve zorg? Waren de doelen realistisch, zoals bijvoorbeeld het streven naar arbocuratieve samenwerking? Huisartsen denken dan vaak aan iets moeizaams, tijdrovends. Afstemming (op strikte indicatie) lijkt haalbaarder: daar kan niemand tegen zijn.

Hier spelen ook gedragspatronen, ingesleten tijdens een eeuw 'Scheiding behandeling-controle'. Daardoor hoefden behandelend artsen zich niet om 'arbeid' te bekommeren. Dat buig je niet zomaar om. Intrigerend genoeg blijkt uit een recent internationaal project, dat buitenlandse behandelend artsen die wél ziekenbriefjes schrijven, ook vaak een 'blinde vlek voor werk' hebben. De financiering is eveneens problematisch: zo staat tegenover extra medische inspanningen vaak geen extra 
betaling, terwijl minder verzuim/WAO werkgevers geld bespaart. Voorts ontbreekt vaak wetenschappelijke onderbouwing. Medicijnen worden degelijk getest, maar ziekteverzuiminterventies nauwelijks. De betalers - werkgevers en werknemers - zouden veel meer moeten investeren in onderzoek, om te zorgen, dat ze waar voor hun geld krijgen!

Ten slotte ontbreekt er een goed gecoördineerd, breed gedragen implementatieplan voor beschikbare kennis en instrumenten, met goede monitoring en evaluatie, en voldoende stimulansen voor alle betrokkenen - werknemers bijvoorbeeld via de 'Ziek\&Mondig'-reisgids.

Vergrijzing, werken tot (na) je 65e en strengere WAOeisen zullen onvermijdelijk leiden tot veel meer medische problematiek onder de beroepsbevolking. Wordt dat niet adequaat aangepakt - in goed, demedicaliserend samenspel tussen gezondheidszorg en arbeidsorganisaties, met patiënt/werknemers centraal - dan ondermijnt dat de productiviteit en concurrerend vermogen, en daarmee ons welvaartspeil, inclusief sociale zekerheid en gezondheidszorg. Ziedaar de urgentie van dit dossier! Nu bieden recente ingrijpende wetswijzigingen als WIA, Zorgwet en liberalisering Arbowet de sociale partners veel meer regiemogelijkheden bij de toekomstige vormgeving van 'Gezondheidszorg\&arbeid', door hen ook wel 'ketendienstverlening' genoemd. Tegen deze achtergrond discussieerden op 18 november 2005 in het SER-gebouw werkgevers, werknemers, artsenorganisaties en wetenschap over dit dossier, voor het eerst op voorzittersniveau. Daar bleek niet alleen consensus over de belangrijkste knelpunten, maar werden ook oplossingen gepresenteerd, die breed weerklank vonden, zoals een KNMG-actieplan terzake. Een ad-hoc-werkgroep met vertegenwoordigers van betrokken partijen werkt een vervolgtraject uit. Als lid daarvan heb ik goede hoop, dat het niet nog eens 25 jaar duurt eer dit lastige maar vitale dossier 'Gezondheidszorg\&arbeid' op orde komt! 